\title{
Prodigious Births and Death in Childbirth in Le Palais des Nobles Dames, (Lyons, 1534)
}

\section{BRENDA}

DUNN-

LARDEAU

Summary: In 1534 Pierre de Sainte Lucie published Jehan Du Pré's Le Palais des Nobles Dames in which the treatment of the theme of prodigious births and death in childbirth is of particular interest compared to that of his sixteenth century contemporaries. On the one hand, the author's religious faith enables him to adopt a sympathetic attitude toward certain aspects of pregnancy such as unusual variations in gestation length. On the other hand, the same faith limits Du Pré's critical powers since it prevents him from distinguishing legend from reality. His conception of motherhood is confined to the biological level. Finally, the woodcuts represent midwives still playing a major role in obstetrics in contrast with their growing marginalization by surgeons in the fifteenth and sixteenth centuries.

L

e Palais des Nobles Dames written by Jehan Du Pré was dedicated to chapter is devoted either to countering antifeminist prejudices and accusations, or to praising feminine virtues through a compilation of famous examples, which, following a long tradition, provide evidence themselves in the defence of women. In a dream, the male author is invited to champion the cause of the allegorical "Noblesse féminine," and to report on the prevailing situation. To do so, he tours the thirteen rooms of her castle, where women of all epochs and places are gathered according to the feats or qualities which have made them immortal.

Of these, the eighth room, which describes prodigious and sometimes monstrous births, is interesting because of its feminism and the nature of 
faith upon which it rests. For although the theme of prodigious births is widespread in folklore, legend and myth, it is original that a whole chapter rather than a mere allusion in passing should be devoted to that particular subject. Within the feminist compilation genre, the more familiar themes are beauty, chastity, faithfulness, intelligence, etc. ${ }^{2}$

The last room of Le Palais, devoted to death in childbirth, lists macabre prodigies. The author bravely sets out to report on women's courage in childbirth. And, perhaps because men were not usually admitted at birth, what he witnesses in the birth chamber, in the process of being turned into a death chamber, makes him "all dizzy" ("tout estourdy") before he can take heart and resume his task.

\section{Prodigious Births}

The eighth room brings the author into contact with five aspects of pregnancy: the mother's age, the length of gestation period, multiple births and monstrous births, and the importance of giving birth to a son. We will deal with each aspect in that order.

Half of the examples relating to the mother's age are biblical. The early childbirth of Pharoah's daughter, Solomon's wife (1 Kings 3:1), stands in contrast to the pregnancies of Sarah at age 90 (Gen. 17:19) and the advanced age of Elizabeth (Luke 1:36), who had been thought of as being sterile (Luke 1:7). A little later, a seven-year-old busily breast-feeding and a five-year-old resting after labour provide two amazingly precocious cases. Both are from Pliny's Natural History (Book VII, chap. II). ${ }^{3}$ At the other extreme is the pregnancy of Cornelia of the Scipio family. On the basis that Lucius Volusius Saturnius was 62 when he fathered a son (Pliny, Natural History, Book VII, chap. VII) Du Pré infers that so too was his wife Cornelia. Such a transfer of a specific age from one spouse to another was a frequent literary device at the time.

One can see that the cases presented offer more than a mere listing of astounding irregularities. They reflect the author's syncretism of all forms of knowledge, whether biblical, historical, or legendary. Even the title "Dame," applied to Sarah, an Old Testament figure, illustrates this tendency. Du Pré's unshakable belief in biblical teaching is succinctly expressed in the following lines: "Mais Dieu a qui tout est facile / Luy remonstrast que riens n'est difficile" (1.4474-75). The original of this paraphrase "for with God nothing shall be impossible" (Luke 1:37) actually refers, not to Sarah, wife of Abraham, but to Elizabeth, the mother of Saint John the Baptist. In using 
it in connection with Sarah, therefore, the author assigns to it a more general application while conforming to the traditional pattern of feminist champions who use the Scriptures as an authority.

Another source of amazement for Du Pré is the question of variety in the length of gestation period which had been the subject of many a debate among Greek and Roman doctors, jurists, and philosophers. In 1531, three years before Le Palais was written, Andrea Alciati discussed the controversy again in his Problemata followed by Tiraqueau in 1535 in his Commentary on the Law, "Si unquam." At issue was not only the natural phenomenon per $s e$, but the legal aspects as well. The scientific knowledge of the shortest and longest pregnancies was to be used to try cases of affiliation involving legitimate children and rightful heirs. Sometimes these discussions deteriorated into spicy stories with chuckles about the virginity of young brides giving birth eleven months after their husbands' death. Rabelais himself was not averse to indulging in this popular vein of comedy, albeit set against the background of the latest scientific and legal knowledge of his day. ${ }^{4}$

As for the author of Le Palais he makes his point clear with two examples. One concerns a German woman who went through a 22-year pregnancy. Farfetched medieval ignorance, the modern reader may think. Not necessarily, however, if one considers the medical opinion of Ambroise Paré, the Renaissance doctor, remembered for his pioneering work in experimental methods. In his Des monstres et prodiges (1573) he examined gestation periods ranging from 4 to 28 years and concluded that these mothers sat too long, kept their legs crossed, or wore their corsets too tightly. ${ }^{5}$

$\mathrm{Du}$ Pré's second example is borrowed - and simplified to the point of obscurity - from Pliny's Natural History (Book VII, chap. IV) where longer than usual gestation periods are signs foretelling the destiny of famous children. The case referred to concerns Vistilia, a distinguished Roman, who experienced three extremely short gestations as well as an eleven-month one. What is implied in Du Pré's use of this example is a defence of women whose physiology does not conform to the usual norms. Equally important is the fact that Du Pré does not rely on Pliny's authority uncritically as he discards what pertains to divination to focus on the bare facts and the happy outcome whereby these variations in length of gestation were not detrimental to the offspring: "Sans que par ce, ilz fussent plus transis" (1. 4526).

The initial response to this chapter of Du Pré's work may understandably be that it is backward and ignorant, yet such a judgment is unfair in light of some of his contemporaries. The same acceptance of Nature's marvels 
can be found in Ambroise Paré's Des monstres et des prodiges. In it, he affirms that to doubt the might of God and Nature would be impertinent.

The third aspect of pregnancy to be examined, that of multiple births, puts to the test Du Pré's acceptance of natura naturans. ${ }^{6}$ It is of little surprise that Renaissance discussions on fertility should emphasize the traditional duties of motherhood in laudatory terms. Women of the time faced their numerous pregnancies with much courage, despite the uncertain conditions of delivery and the high mortality rate of both mothers and infants. Yet if pregnancy was dangerous, sterility was shameful, as shameful as in biblical times (Gen. 1:25). I can find but one author of this period who discouraged women from countless pregnancies. Louis Vivès in his De institutione foeminae christianae (1523) invited women to stop viewing barrenness as a curse. He saw the role of motherhood going well beyond the biological element, i.e. that of giving birth, and he expressed concern over the difficult task of rearing children. ${ }^{7}$

Most of the extravagant tales of room eight of Le Palais have to do with women endeavouring, or so it seems, to surpass each other in unbridled fertility. In the catalogue of unknown mothers held up for praise, only the number of babies produced is mentioned, 70 here, 150 elsewhere. In the light of these prodigies, twins are hardly worth mentioning unless they come in a row as did Fausta's (lines 4505-06), whose case was inaccurately borrowed from Pliny (Natural History, Book VII, chap. III). Du Pré himself comments that two sets of male and female twins are not "grans nouvelles." In that context of course, triplets are not unusual, either.

Still borrowing from Pliny's Natural History, Du Pré uses three other examples of multiple births (Book VII, chap. III), one of four sets of quintuplets, one of septuplets, and one of a mother of 30 children. What Du Pré is careful to leave out are Pliny's repeated comments that while it is possible to bring forth more than three children at one birth, it is also monstrous and portends some mishap. On the other hand, Aristotle did not believe a woman could bring forth more than five children at one birth.

Drawing on Greek mythology, the author evokes the famous fruitfulness of Comba, daughter of the river-god Asopos. The name of Priam's wife, Hecuba, also appears, though without specific mention of her 19 children, for the author considers this case common knowledge. Both are attributed to Homer's Illiad, but Ovid's Metamorphoses (VII, 382 and XIII, 422) appears likelier. At this point, Du Pré is tempted to doubt the truthfulness of a mother breast feeding her 150 newborns: 

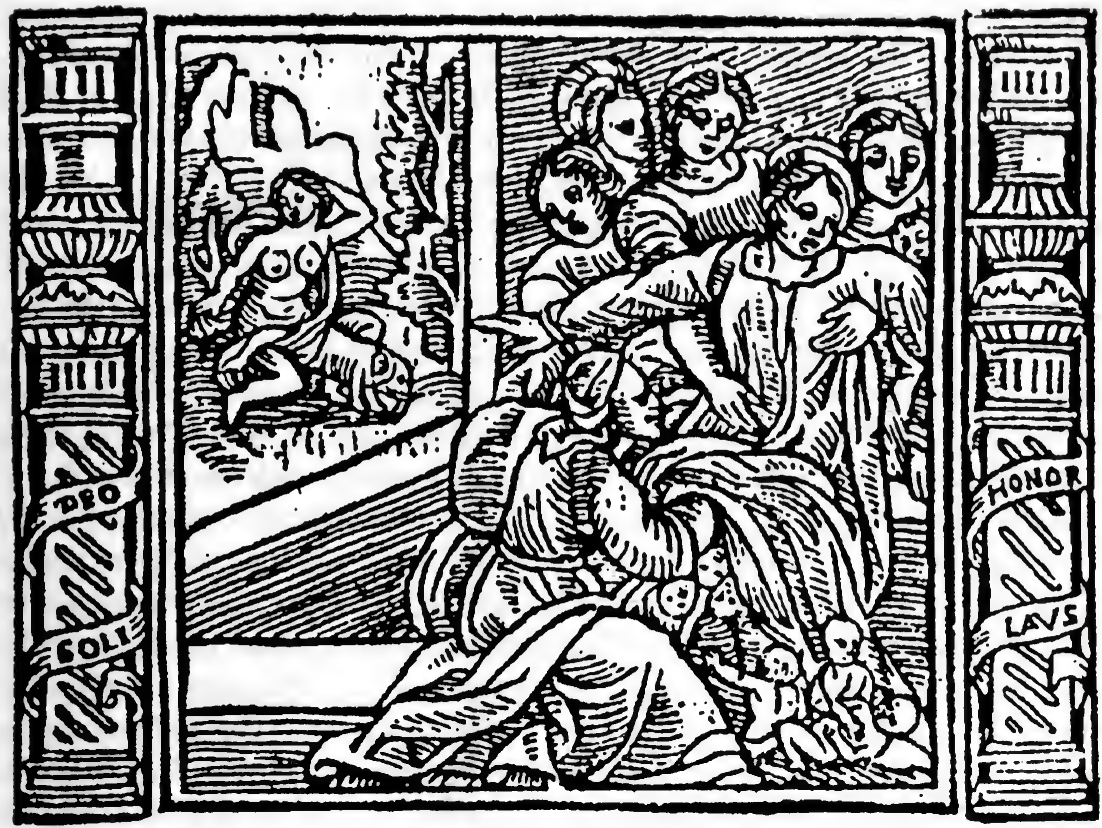

Illustration 1

Les allectoit, comme veis doucement.

Et me pensoye que ce fust faulcement, Jusques a ce que par grant merveille, Me fust monstree chose tant nonpareille Qu'on ayt onc veu en anticque legende.

(1. 4493-97)

The author is opportunely shown the case of the Dutch countess, which is astonishing by any standard. Yet the narrator insists on its veracity: "La, le compta de sa parole mesme" (1. 4502). Such a strong affirmation is part of the Renaissance writer's stock devices for controlling realism in the narrative point of view, but more important, the moral lesson derived from this story applies to the rest of the chapter's lesser prodigies. It grounds Du Pré's list of exempla in religious truth rather than fiction excluding any critical debate from the reader. The passage devoted to the Dutch countess (1. 4498-4502) forms a truncated variant of an example from Jean Mancel's 
Mare historiarum (1488), an author Du Pré lists in his bibliographical catalogue at the opening of his book. In this exemplum, it is said that God, for whom nothing is difficult, allowed the countess to give birth to 365 children because of her refusal to believe that twins could be fathered by the same man. Du Pré grants that she had made fun of her neighbours, which implies that the births might have been a punishment. This rationalization is typical of medieval hagiographical marvels whereby God intervenes to prove his might and, perhaps, his wrath. As a consequence, which part of the story is based on reality and which part on legend remains unchallenged. Another consideration is that numbers such as 365 are readily associated with either symbolic or mythical meaning, but not so with Du Pré who shudders at the mere thought of doubting legendary material preferring a credulous attitude to a critical one for fear of showing lack of faith.

The bibliographer Hugh Davies has followed the fortune of this unlikely story. After Mancel and Du Pré, it reappears in the Controverses des sexes masculin et féminin (1534) by the antifeminist Gratien Du Pont and as late as 1560 in Boaistuau's Histoires prodigieuses. ${ }^{8}$ A 1578 mention may be added as the story is also found in L. Joubert's La Première et la seconde partie des erreurs populaires touchant la médecine et le régime de santé with only 363 births left. According to Davies, it is the Dutch countess, attended by a midwife and four other women, who fills the foreground of the woodcut shown in chapter eight of Le Palais (Illustration 1).

It is certainly not our intention to denigrate a mother's real pride for the children she has borne and fed. However, such a display of competitive fertility as Du Pré presents limits the mother's role to that of an ever-fertile and devoted wet-nurse. The factual, enumerative tone in Le Palais may become irritating to a modern reader but is not unusual for its period. ${ }^{9}$ But why then such a burst of interest in mothers happily breast feeding, and especially the mythical Comba:

Après, Comba prenoit plaisir extresme

A bien nourrir de ses filz le centiesme.

$$
\text { (I, 4509-4510) }
$$

This repeated praise of mothers breast feeding in five instances accompanied with the joy often derived from it has didactic overtones and is more atune with a plea for maternal breast feeding as it chimes in with other sixteenthcentury advocates of the practice. As Évelyne Berriot-Salvadore explains, special efforts were made by doctors and moralists to boast the pleasures of 
breast feeding and the bondage it established between mother and child in order to divert, mostly well-to-do mothers, from turning over their infants to wet-nurses for mundane social and esthetic reasons. Another argument, she adds, given to encourage mothers to breast feed their own children, was the medical opinion according to which the blood that fed the fetus turned into milk at birth, thereby suggesting that it would be less wholesome to let another woman than the mother be in charge of this task. ${ }^{10}$

Nonetheless, how far we have come from Rabelais' Gargantua, written two years earlier, in which Grandgousier interrupts his meal at La Saulsaye to comfort with simplicity and feeling his wife, Gargamelle, who is experiencing the first pangs of labour!

Let us turn now to the complex question of individual monsters as a kind of prodigy (as Du Pré remains unconcerned with monstrous races). The relationship of monsters with Nature has been thoroughly investigated by Jean Céard. ${ }^{11}$ For Aristotle, they are a mistake of Nature. For Pliny, sensitive to the strength and majesty of Nature, monsters illustrate the diversity of Nature even when the latter does not follow its common course. This very notion of the common course of Nature is central to Du Pré's rubric heading this chapter: "L'autheur en la huytiesme chambre, trouva les Dames qui ont enfanté contre le commun cours de la nature, et en plus grand nombre que facilement on en peult croire."

While Pliny does not look for signs in meteorological happenings such as lightning, he does see some in prodigies. In the case of individual monsters, they represent bad omens. The problem for the Middle Ages and Renaissance was that the belief in omens was superstitious, hence contrary to Christian faith. This difficulty was circumvented by revising Pliny. His admiration for Nature was put to the service of God's creation while Nature's bad omens became signs sent by God. Another method limited itself to using Pliny as a generous provider of marvels, of which medieval and Renaissance readers never seemed to tire.

In chapter eight of Le Palais, there are three examples of monstrous births. The following two are borrowed from Pliny's Natural History (Book VII, chap. III). Alcippe, who gave birth to an elephant, was portrayed among the marvels decorating Pompey's theatre. Apart from Pliny, there is a mention of Glaucippe in Tatian (Or. adl. Graecos, chap. 33) which probably refers to the same mythological character about which information is scant. The ill-fated Alcippe (not to be confused with the daughter of Ares bearing the same name) is pictured in the background of the woodcut at the beginning 
of chapter eight of Le Palais (See illustration 2) in the act of giving birth to the monster; and as late as 1576 Sylvain mentions her again in his Recueil des Dames illustres en vertu. ... Concerning actual elephants, Hélène Naïs has indicated that in 1550 an elephant was part of the triumphant entry of Henry II into Rouen, but perhaps Du Pré, who fought the battle of Pavia, may have seen one in Italy where the presence of elephants was constant in fifteenth- and sixteenth-century menageries. ${ }^{12}$ This last possibility does not explain, however, the meaning of the realistic looking elephant in such an unrealistic situation, but then, even Pliny had not expressed any doubt before Alcippe's case. ${ }^{13}$

Closer to our problem are the motifs that appear in the dreams of pregnant women: according to an ancient Buddhist tradition, the mother of Buddha dreamed that a white elephant had entered her womb. In western tradition, variants of that dream motif are not uncommon in hagiographic literature. In the Legenda aurea (thirteenth century), for instance, St. Dominic's mother dreams that she is giving birth to a dog brandishing a firebrand in his mouth. As the Legenda aurea was still immensely popular in Du Pré's time it may be assumed that the idea, at least at an allegorical level, of a woman giving birth to an animal, was perceived neither as alien nor as astonishing as it would seem at first. In the case of Alcippe though, the dream becomes reality. At any rate, the portrayal of Alcippe and the Dutch countess on the woodcut obviously filled the readers' craving for the unusual and leaves us with the impression of having witnessed mythic figures turned into human beings.

The second case of monstrous birth in Le Palais (1. 4535-37) refers to a deadly snake born to a maidservant at the beginning of the Marsian War. Once again, Pliny's portentous explanation for monstrous births is omitted, but this time there is a noticeable change of tone:

Encores vers ung faict plus merveilleux;

Ung grant serpent villain et perilleux

Sortoit du corps d'une pouvre chambriere

(1. 4535-37)

Expressions of compassion appear such as "pouvre chambriere" for the slave's ordeal or "piteuse manière" to describe Alcippe's plight. Never are these marvels, culled from Pliny, put on the count of gross bestiality. However, Du Pré's pity is momentary, for the sight of bearded and greyhaired babies amuses him (1. 4514-17). In his Etymologiae (seventh century), 
Isidore of Seville had already classified precocious signs of old age in new-born babies as a characteristic of human monsters. ${ }^{14}$ Yet even though the name of Isidore de Seville appears in Du Pré's bibliographical catalogue, one strongly suspects Pliny of being a more likely source (Natural History, Book VII, chap. XII) of this ancient motif for which the fountainhead is Hesiod (Works and Days, 181).

The study of Du Pré's sources shows that Du Pré handles this type of prodigious birth cautiously because of his faith in God. The stock expression of pity and the laughter these marvels cause him do not, however, enable the reader to forget the vigorous didactic style of Les Evangiles des Quenouilles nor the latter's attempt to provide a human rather than divine explanation for monstrous births. ${ }^{15}$

Finally, compared to the major authorities on monstrous births, Jehan Du Pré's attitude is neither scientific or medical (Aristotle), nor one considering these births as signs given by the gods for divination (Cicero) or portents (Pliny). It is also remote from Augustine's stand who views monsters at times as marvels no less marvelous than normal beings and at others as a demonstration of God's anger before sin. Closer to Pliny, if one sets aside the idea of the monster as a portent, Du Pré eagerly compiles facts going against the common course of Nature and then proceeds to christianize this material by ascribing its existence to the glory of God and sometimes to his anger, though not before sin but lack of faith. ${ }^{16}$

Far removed from the already discussed aspects of pregnancy but of equal concern for the period is the fifth motif, the importance of giving birth to a son, which rests on no specific test, though customs such as patrilineage or rights of primogeniture support this cross-cultural attitude. All but one of the women Du Pré praises owe their fame to their sons. Here both feminists and antifeminists share a long common tradition which may be an Aristotelian reminiscence. According to Aristotle, Nature formed women as a result of some material imperfection only if it could not produce a normal and perfect human being, namely a male. Medieval and Renaissance antifeminists still frequently attacked women as imperfect beings. ${ }^{17}$

To be fair, however, one must concede that inasmuch as Du Pré's choice of examples reflects a preference for sons, his numerous accounts of prodigious births which seldom mention the role of the male may be an indication of the importance he attributed to women in this area. In such a case, one welcomes a position on the role of women in procreation different than that 


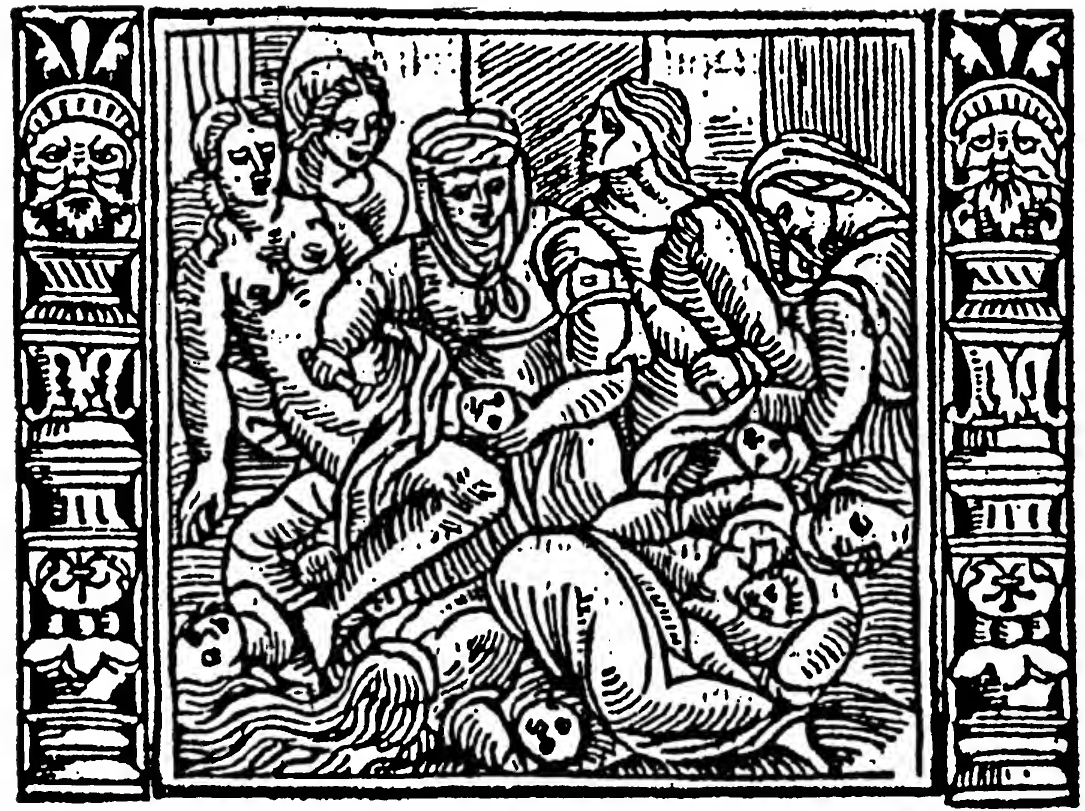

Illustration 2

of Aristotle who considered women as a mere passive receptacle for male semen.

In true medieval fashion, Du Pré has kept for the last his homage to the Virgin Mary, who surpasses all women by her immaculate conception of Jesus Christ. It is also an allusion to a traditional feminist argument from the Scriptures: a woman has conceived God, which is impossible for a man to do, hence her superiority in the area of conception. ${ }^{18}$ Most of all, Du Pré is adamant about keeping an orthodox Catholic position on the immaculate conception, leaving no room for contradiction, as he writes:

S'il vous plaisoit, O pucelle de pris,

Prendre plaisir que mes rudes escriptz

Vous ramenteissent, alors je pourroy dire

Sans que nully y osast contredire,

Que vostre faict, toute nature passe,

(1. 4555-59) 
The purpose of such a collage of biblical, historical and legendary examples was obviously meant to express an understanding, though admittedly amazed attitude before all forms of human nature. Du Pré's synthetic vision of the world, marked by his reliance on the authority of Pliny and others, along with an unwavering faith in the Bible, lead him to give credit to all reported prodigious material and reinterpret his sources within the safe limits of traditional Christian dogma.

The last aspect of this study, i.e. death in childbirth, is dealt with separately in the last room in Le Palais, on which Jehan Du Pré reports, although it may also be linked to prodigious births.

\section{Death in Childbirth}

The author longs to see this last room ("Quand je parvins ou mon coeur pretendoit, / Assavoir est, en chambre derniere"). For this reason he overcomes his repeated discomfort before death in childbirth, grateful no one prevents him from his quest. Considering the mentality of the fifteenth and sixteenth centuries Du Pré is showing some sense of daring (even if within the framework of a dream!) as the birth chamber is the exclusive domain of women except for special cases such as caesarian sections for which a male surgeon (which Du Pré is not) is called in, by then, more often than a midwife. ${ }^{19}$

To tackle the tragedy of death in childbirth, Du Pré has put together 55 decasyllables from cases borrowed from ancient pagan historical and mythological sources, Pliny especially, except for that of Rachel (Gen. 35:16-20).

To be sure this theme rests incontestably on the real danger of delivery women faced. However, despite the pain and the death involved, these exempla do not appear to support the biblical curse (Gen. 3:16) whereby the pain of childbirth is a reminder of the fact that woman was the first to sin. In the pagan tradition, death in childbirth signifies that children whose mothers die in childbirth are born under better omens (Pliny, Natural History, Book VII, chap. VII, parag. 1). This belief can still be traced in the literature of giants which thrived in the medieval and Renaissance period. In Folengo's Le maccheronee, one of Rabelais' sources, Balduina, the mother of Baldus, dies in childbirth. ${ }^{20}$ In Pantagruel, the birth of Pantagruel (chap. 2) is the cause of Badebec's death as the new-born "estoit si merveilleusement grand et si lourd qu'il ne peut venir a lumière sans ainsi sufocquer sa mere." 
Interestingly enough, Du Pré does not follow this course markedly as the only child promised to fame is Rachel's Benjamin, the others being designated in a general and anonymous manner as enfantet or the standard medieval metaphor son fruict. These mothers owe their fame to themselves (the goddess Athena, the biblical Rachel) or to their kinship (the mother of Codrus Urceus, wife of Pompey or daughter of Cicero). In this last case a moving note is reached when Tuliola is said to endure her own death more willingly knowing that her child is stillborn. If the author shuns divination he also remains silent with respect to the widespread tradition of prayers to St. Marguerite, the patron of pregnant woman, not to mention those to the Virgin Mary, the mother above all mothers, but this may also be due to the fact that these women are pre-Christian heroines.

As for the last exemplum of death in childbirth in chapter eight it is linked to monstrous births. In it Du Pré recalls the famous case recorded by Pliny of the child from the ancient Saguntum who is said to have gone back to his mother's womb after his birth during Hannibal's ransack of the town in 219 B.C., thereby killing his mother (Pliny, Natural History, Book VII, chap. III, parag. II). As with other borrowings from Pliny, Du Pré does not dwell on the portentous nature of the deed but its marvelously awesome quality to cap off his collection of "choses merveilleuses touchant l'enfantement":

Pour faire fin, me fust dict ung hault compte

Et nompareil, advenu en Sagonte;

Although no contemporary cases of death in childbirth are given, one may note a reference to a medical practice still alive in Du Pré's day when child labour was not normal. In her book on caesarian birth in medieval and Renaissance culture, Renate Blumenfeld-Kosinski explains that keeping the mother's mouth and vagina open were two measures "supposed to prevent the suffocation of the fetus." 21 This technique which was also extended to the body of a dead mother in the hope of saving her fetus, if not its body, at least its soul by baptism in utero. But the gesture here combines the scientific and the religious so that Nature is defied in a miraculous way as the mother is brought back to life:

Heraclides, par son engin subtil,

Faisoit revivre avec son outil

Une matrosne, illec morte estendue, 


\begin{abstract}
Et luy estoit plaine vye rendue;
Et nonobstant que de sept jours l'espace

Eust esté morte, il luy fist ceste grace

En luy ouvrant sa partie secrete.
\end{abstract}

Finally the woodcut, especially designed for this chapter, is of interest as it illustrates with some sense of drama a contemporary birth chamber filled with women in the process of delivery, some lying on the floor recovering from childbirth perhaps, others moribund or already dead (see Illustration 2). The illustrator may be said to have followed the contents of the chapter in a loose way as it is the intensity of the moment of birth which he has chosen to convey and not the grimness of death on which Du Pré has focused his attention.

Indeed, the central figure is obviously a capable and energetic midwife, wearing a special headdress, and shown very competently delivering a baby holding a speculum in one hand and pulling the baby out with the other. The mother, half-sitting, half-reclining, does not seem to be sitting on a birth stool. ${ }^{22}$ She is partly naked with a sheet modestly covering her lower belly and perhaps used later to cover the baby. She is being attended by other women, friends or neighbours who are supporting her back and shoulders. The other mothers seen delivering are fully dressed. ${ }^{23}$ On the right, a second midwife, using the same procedure as the first one, is in the midst of delivering a baby from a woman showing strain from labour or perhaps grieving her stillborn.

The figure on the lower right hand corner may be illustrating a variant of another method of delivery called the hanging-legs position, also the Scipione Mercurio posture and later the Walcher position. Harold Speert explains that it was "First described by Albucasis (936-1013) and advocated by Avicenna (c. 979-1037) for the delivery of obese patients, to facilitate exposure of the vulva." $24 \mathrm{He}$ adds that this position, illustrated in Scipione Mercurio's famous textbook La Comare o Raccoglitrice (1595), is redescribed by Sebastiano Melli (1721) in his book for midwives La Comare in the following way: "The midwife takes two or three cushions or bolsters, arranging them in such a manner that only the back of the patient is supported when placed upon it, so that the abdomen protrudes and the head hangs downward to the floor. The patient being placed firmly upon the bolsters, she will bend her feet inward toward the pelvis, a posture that tends to enlarge the vagina, rendering it possible for women, however fat, to be delivered 


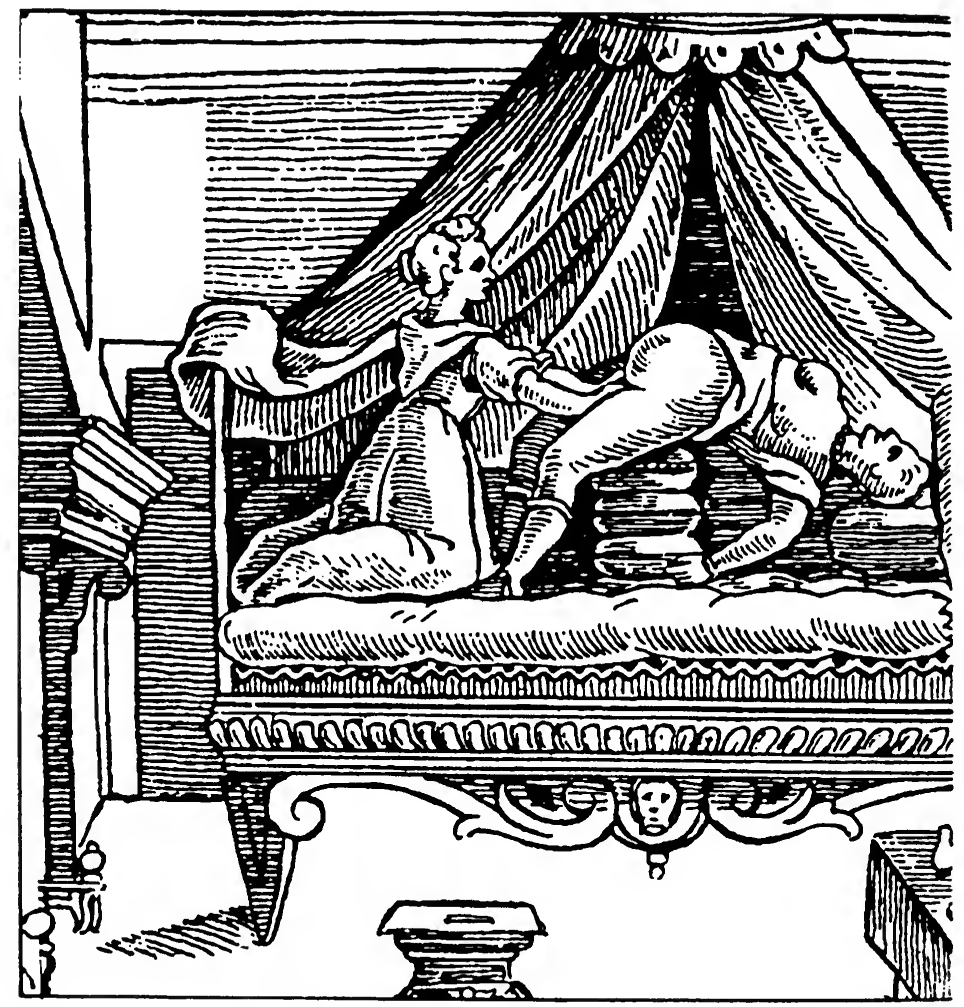

\section{Illustration 3}

with ease, because the corpulency of the abdomen in this posture ... does not interfere with the child's normal birth"25 (see Illustration $3^{26}$ ).

Other illustrations of the hanging-legs position show women with legs hanging with back lying straight instead of bent backwards and head hanging downward to the floor but without knees bent (see Illustration $4^{27}$ ).

In this light, the illustration in Le Palais remains ambiguous perhaps because there may have been an intermediary between the unknown artist and the wood-cutter, the latter trying to make sense of this position by banalizing it. Indeed, if one looks closely at the bulge at the foreground it may appear as the stomach of the parturient mother at the right or as the buttocks of the one lying on the left. However, if the latter position proved 
right it would be, in contradiction with anatomy whether one sees the woman resting on her back or on her stomach, a mistake in the axis of the limbs and the torso which jars with that of the other characters. And should the figure on the right be in a hanging-legs position, then one would have to take into account one more variation of the position as the mother's torso is half reclining. Be it as it may, since this position was taught to midwives it cannot be discarded as unlikely that it should appear in an illustration depicting them in full operation with at risk deliveries. ${ }^{28}$

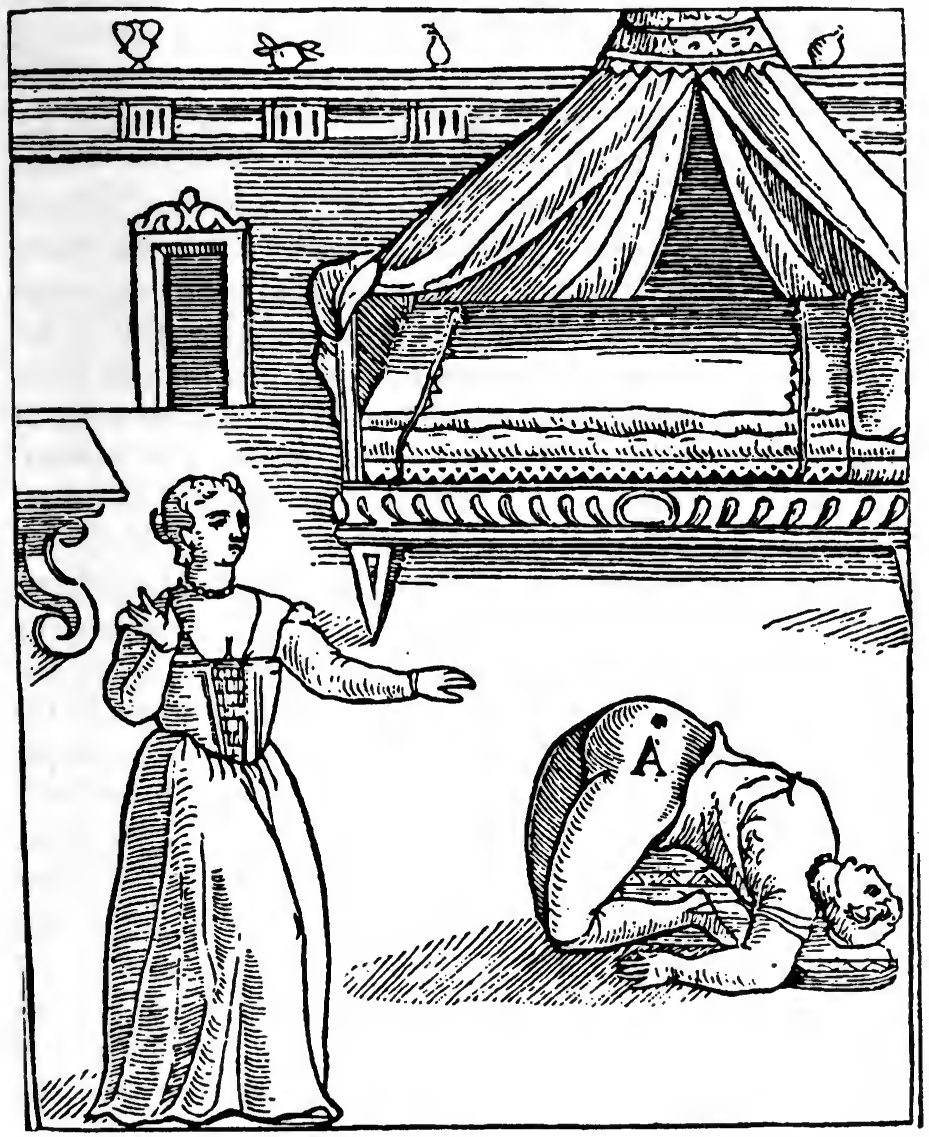

Illustration 4 
Finally, perhaps because the whole of the scene is shown "in the act" of delivery, instead of the more common "moment after the actual birth" as with nativity illustrations, the infants have not yet been wrapped in swaddling clothes as was customary.

Chapters eight and nine in Le Palais contribute to the abundant medieval and Renaissance literature of prodigies and are examples of traditional feminism. The chapters are organized according to a traditional pattern whereby arguments from the Scriptures are supported by long lists of famous examples. The substance of the praise is equally traditional, resting firmly on faith in the astonishing powers of God the Creator to such a degree that legend may never be distinguished from reality. The deletion of Pliny's interpretation of certain prodigies as signs and portents is therefore probably not the mere result of borrowing Pliny through Ravisius Textor's anthology as exempla from the Natural History are consistently christianized. While Du Pré steers away from such overt pagan superstition as well as prayers to St. Margaret, both contrary to the evangelical christianism of Marguerite de Navarre to whom the book was dedicated, there remains an occasional tinge of God's anger in the monstrous births he encounters as the example of the Dutch countess illustrates but not as retribution for sins, but lack of faith. This negative slant does not overpower the author's fervent wish to be in total awe before the creator's marvels and the accomplishments of women.

There are no attacks on the role of women in procreation in Le Palais but then nothing appears to enhance it either, apart from his praise of the joy of breast feeding one's own children, as Du Pré's understanding of childbirth remains bookish. In addition, the number and type of marvels tend to sway out attention from the role of women in this area to the unlimited powers of God and the variety of Nature. Yet, it cannot be dismissed that within the antifeminist current of thought, the cases of length of gestation and multiple births, for instance, put forth by Du Pré, would readily have been linked with superfetation. In this respect, Du Pré's writing is free of the meanness of the antifeminist tradition always quick to find an explanation for such irregularities to the disadvantage of the reputation of women. Thus, this author may be considered a feminist in chapter eight of Le Palais because of his acceptance of variety in several aspects of childbirth as the age of mother, the length of gestation period, multiple births and even certain kinds of monstrous births as well as his recognition of mothers dying in childbirth in the last room. 
Finally, the fact that both woodcuts for these chapters represent midwives in the act of delivering babies in difficult circumstances, whether real or legendary, is an implicit acknowledgement of their role in sixteenth-century medical practice at least in the mentality of the provincial seigneur Jehan Du Pré. He may be bookish and his style awkward, but it remains that he may be commended for surmounting his own fears surrounding the mysteries of birth and the birth chamber so that "Noblesse feminine" may be justly defended and duly appreciated.

\section{Université du Québec à Montréal}

\section{Notes}

1. Le Palais des Nobles Dames, or simply Le Palais will be used hereafter. Excerpts are taken from the copy in the Musée Condé in Chantilly, listed item no. 684 in the catalogue Le cabinet des livres. Imprimés antérieurs au XVI $s$. We thank the Bibliothèque Nationale de France for permission to reproduce the two illustrations from Le Palais taken from Rés. Ye 1254.

2. The following works are representative of the compilation genre and the first and third books listed have also provided Du Pré with examples of famous women for several passages in Le Palais: Boccace, Le livre de Jehan Bocasse, De la louange et vertu des nobles et cleres dames, translaté par Laurent de Premierfait (Paris, Antoine Vérard, 1493); Jean Bouchet, Le temple de bonne renommee et repos des hommes et des femmes illustres, trouvee par le Traverseur (1516); Ravisius Textor, De memorabilis et claris mulieribus aliquot diversorum opera (Paris, Simon Colines, 1521). The medieval compilation tradition is still found at the end of the sixteenth century in Alexandre van der Bussche, dit Sylvain de Flandres, Recueil des Dames illustres en vertu, ensemble un Dialogue de l'amour honneste, plus un discours poetique des miseres de ce monde (Paris, 1576, rééd. Lyon, 1581).

3. All subsequent references to Pliny are from: Plinius Secundus, Natural History, trans. H. Rackham, ed. W. Heinemann (Cambridge, MA: Harvard University Press, 1937), vol. II. As For Du Pré his use of Pliny is second-hand as he borrows his examples (complete with typographical mistakes) from a well-known sixteenth-century anthology by Ravisius Textor (see note 2), a convenient reference book, even the erudite Rabelais was not adverse to using. This reading of Pliny through Ravisius Textor's editing of his work puts a damper on the extent of Du Pré's critical powers.

4. Michael A. Screech, "Eleven-month Pregancies: A Legal and Medical Quarrel A Propos of Gargantua. Chaper Three Rabelais, Alciati and Tiraqueau," Études Rabelaisiennes, 8 (1969), 93-106. Both Rabelais (in chapter 3 of Gargantua, 1534) and Du Pré (1. 4474-75) quote Luke 1:37, "for with God nothing shall be impossible," because it was recognized as one of the texts on which the nature of faith is based. Nevertheless, Rabelais' mocking use of it shows that it is not the Bible that he ridicules of but those who equate faith with mere belief which to his eyes neared superstition, as Michael A, Screech has analyzed in "L'évangélisme de Rabelais. Aspects de la satire religieuse au $\mathrm{XVI}^{\mathrm{e}}$ s.," Études 
Rabelaisiennes, 2(1959), 10-22. Lest it be forgotten that the efforts to relate scientific views to the birth of Christ have been the concern of Catholic writers and physicians alone, Joyce Irwin's article on that topic should be noted. Of the three Protestant figures she studies, all seek confirmation of their different scientific positions in the Scripture, be it Menno Simons who takes a distorted Aristotelian view of generation or Guy de Bres and Michael Servatus who adopt Galenic ideas. Only Servetus is able to account for this exceptional birth without resorting to the miraculous, but then his "scientific" explanation, a blend of science and theology, is dubious. See Joyce Irwin, "Embryology and the Incarnation: A Sixteenth-Century Debate," Sixteenth Century Journal, IX, 3 (1978), 93-104.

5. Ambroise Paré, Des monstres et prodiges, ed. Jean Céard (Geneva: Droz, 1971).

6. While multiple births may be considered simply as prodigies, $D$. Wilson states that in the Mémoires-Journaux of Pierre L'Estoile, a collector of curiosities whose diary was kept from the end of the sixteenth century to the beginning of the seventeenth, but published in the nineteenth century only: "Multiple births are recorded as being almost as worthy of note as monstrous births: triplets [ ... ], quadruplets [ ... ], and, associated with a magic number, the case of a young woman in Paris, near the "Eschelle du Temple," who gave birth, at seven months, to seven children, six of which were stillborn [ ... ]." Wilson explains that by that time attention paid to the monster steers away from the superstitious to be linked to the curious and the scientific. Dudley Wilson, Signs and Portents: Monstrous Births from the Middle Ages to the Enlightenment (London and New York: Routledge, 1993), pp. 83 and 72.

7. Jean Loys Vivès, Livre de l'institution de la femme chrestienne tant en son enfance que mariage et viduité, nouvellement traduictz en langue françoyse par Pierre de Changy, escuyer [1542], avec préface et glossaire par A. Delbouille (Geneva: Slatkine Reprints, 1970 [1891], pp. 233 and especially 234: "Saches que la malediction ancienne de la sterilité est passée."

8. Hugh Davies, Catalogue of a Collection of Early French Books in the Library of C. Fairfax Murray (London: Privately printed, MDCCCCX).

9. For a similar tone within the compilation genre, see the 1504 Les Vies des femmes célèbres by Antoine Dufour, ed. G. Jeanneau (Geneva: Droz, 1970).

10. Évelyne Berriot-Salvadore, Un Corps, un destin. La femme dans la médecine de la Renaissance (Paris: Honoré Champion, 1993), pp. 187-196.

11. Jean Céard, La Nature et les prodiges: L'insolite au XVI siècle, en France (Geneva: Droz, 1977).

12. Hélène Naïs. Les animaux dans la poésie française de la Renaissance (Paris: Didier, 1961), pp. 146-147.

13. In iconography and literature, the elephant carrying a castle symbolized strength or was interpreted as a moral allegory representing Christ as in the Physiologus (tenth c.), both meanings are apparently unrelated to Alcippe's case. For that aspect, see G. C. Druce, "The Elephant in Medieval Legend and Art," Archeological Journal, 76 (1919), 1-73; William S. Hechscher, "Bernini's Elephant and Obelisk," Art Bulletin, 29 (1947), 155-182; Beryl 
Rowland, Animals with Human Faces (Knoxville: University of Tennessee Press, 1973), pp. 70-74.

14. Bruno Roy, "En marge du monde connu: les races de monstres," Aspects de la marginalité au Moyen Âge, ed. Guy-H. Allard (Montreal: L'Aurore, 1975).

15. P. Janet, Les Evangiles des Quenouilles (Paris, 1855), partial rpt. Madeleine Jeay, “Choix et croyances relatives aux tabous sexuels, au mariage et à la grossesse, tirées des Evangiles des Quenouilles, in L'érotisme au Moyen Âge, ed. Bruno Roy (Montreal: L'Aurore, 1977). In this collection of popular beliefs, pregnant women are advised in a direct and practicalminded approach to avoid certain foods which might produce physical defects in their babies: soft cheese will only cause malformations in male and female sexual organs (too small in one case, too large in the other) and because of the effect on their imaginations, eating the head of a hare may produce a hare-lipped baby; the head of fish, one with fish-like eyes and mouth.

16. See Dudley Wilson, Ibid., pp. 14-24 for a detailed presentation of these four positions on monstrous births in the Renaissance as well as Jean Céard for these and other positions held on monsters from Aristotle to Ambroise Paré. The medieval Augustinean tradition of explaining monsters as a result of sin is still found in chap. 5 "Histoires des enfantemens monstrueux, \& de la cause de leur génération” in Pierre Boaistuau's Histoires prodigieuses (1582). Also, it must be pointed out that the attitude deeming the monster as the wrath of God is still alive in Protestant circles as the following publication by Melanchton and Luther illustrates: De deux monstres prodigieux à savoir d'un asne-pape qui fut trouvé à Rome en la riviere du Tibre l'an 1496, et d'un veau-moine nay à Friberg en Misni l'an 1582 [1522], qui sont vrais presages de l'ire de Dieu, [ ... ], pour avoir abandonné la vérité de l'Evangile (Geneva, Jean Crespin [Preface by Jean Calvin at the end]. Originally published in German in 1523, translated in French in 1557, and in English in 1579 (work listed by Wilson, Ibid., p. 195, and studied by Céard, Ibid., pp. 75-86).

17. For a study of this persistent attitude, see Évelyne Berriot-Salvadore, Ibid., chap. II, "L'imperfection radicale," pp. 17-32.

18. For traditional arguments in feminist as well as antifeminist debates in the Middle Ages and Renaissance, see Marc Angenot, Les champions des femmes (Montreal: Presses de l'Université du Québec, 1977).

19. Renate Blumenfeld-Kosinski, Not of Woman Born: Representations of Caesarian Birth in Medieval and Renaissance Culture (Ithaca and London: Cornell University Press, 1990). In this book the author shows how in the fifteenth and sixteenth centuries midwives were progressively marginalized in the area of obstetrics, and particularly with respect to the caesarian birth, which became the stronghold of male surgeons.

20. François Rabelais, Pantagruel, ed. Abel Lefranc (Paris: Champion, 1922), t. III, chap. II, p. 30, n. 5.

21. Renate Blumenfeld-Kosinski, Ibid., p. 67. Also Évelyne Berriot-Salvadore (Ibid., p. 169) explains that in the sixteenth century obstetrics textbooks fight this practice resting on ignorance of the anatomy. As for A. Paré he considers it superstitious. 
22. In Jacques Gélis, History of Childbirth: Fertility, Pregnancy and Birth in Early Modern Europe, trans. Rosemary Morris (Cambridge: Polity Press, 1991 [1984]), we are reminded that "Today, lying on the back (dorsal decubitus) has become so general that we forget that it is a comparatively recent practice, acquired only in the last two centuries, in France and Western civilization as a whole. It was common in olden days to bear one's child sitting, crouching, kneeling, even on all fours" (p. 121). He adds "The position for delivery may be brought down to two overall categories: vertical, [ ... ] and horizontal.... (Four positions can be considered as vertical: crouching, kneeling, sitting and standing" (p. 122). Finally "The horizontal position, while not exceptional, principally affected women who had some difficulty in bringing to birth, especially if they had been suffering for many hours, and went exhausted to lie down on a straw mattress or on the bed. [... ] A position midway between sitting and lying was used in the country side, especially in the winter when one had to beware of cold ... the woman was seated on an old mattress or a straw paillasse, leaning her back against a fallen chair [ ... ] this half-sitting, half-lying position was still in use about 1860 in some parts of the Midi" (p. 131).

23. I am indebted to Renate Blumenfeld-Kosinski's chapter on "Caesarian Birth in the Artistic Imagination" (Ibid., pp. 48-90) in helping me to describe the birth scenes in Le Palais. Up to the year 1400 illustrations of caesarian sections show only midwives at work. After that they are gradually excluded from that practice and consequently from the illustrations which picture them as mere helpers or not at all. In the case of the illustration discussed in Le Palais it does not depict a caesarian section but does show difficult labour in a non-medical book with mothers lying on the floor and speculums being used.

24. Harold Speert, Iconographica gyniatrica: A Pictorial History of Gynecology and Obstetrics (Philadelphia: F. A. Davis, 1973), p. 234 for the historical background of this position and the quotation of Melli. It is to be noted that in Scipione Mercurio's La Comare o raccoglitrice the posture is not only recommended for obese patients but also for those with a very narrow womb. Also the posture is accompanied by special ointments to stretch the womb and make the patients relax. As for these parturients, they are left in dim light to preserve their modesty.

25. Harold Speert, Ibid., p. 234.

26. Illustration is taken from Scipione Mercurio, La commare o raccoglitrice (Venice: Francesco Caluasense, 1686), p. 155. We thank The Osler Library of the History of Medicine at McGill University for permission to reproduce this illustration from their collection of rare books.

27. Illustration taken from Scipione Mercurio, Ibid., p. 110. We thank The Osler Library of the History of Medicine at McGill University for permission to reproduce this illustration from their collection of rare books.

28. I am grateful to Professor Faith Wallis from McGill University for a very stimulating and helpful discussion concerning this unique illustration. 